\title{
Spektrofotometryczne oznaczanie zawartości białka w monocytach/makrofagach THP-1 - opis metody
}

\section{Spectrophotometric determination of protein content in THP-1 monocytes/macrophages - description of the method}

\author{
Jolanta Wolska, Katarzyna Janda, Izabela Gutowska \\ Zakład Biochemii i Żywienia Człowieka Pomorskiego Uniwersytetu Medycznego w Szczecinie \\ ul. Broniewskiego 24, 71-460 Szczecin \\ Kierownik: prof. dr hab. n. med. Ewa Stachowska
}

\section{SUMMARY}

Proteins are the basic building block of tissue, and are part of enzymes and hormones regulating many important life processes. Changes in their concentration control the metabolic processes of the cell. Quantitative determination of the protein content is divided into indirect methods (e.g. Kjeldahl method) and direct methods (buret method, Lowry, immunoenzymatic, formol method, based on incorporation of dye in the range of ultraviolet spectrophotometry, and based on the phenomenon of selective absorption of radiation in the infrared range). One of the methods for the determination of protein content is the spectrophotometric method described by Bradford. The protein concentration assay procedure utilizes the phenomenon of formation of the dye (Coomassie Brillant Blue G-250)-protein and colour intensity is proportional to the protein content in the solution.

The aim of this study was to verify the usefulness of this method for determining the protein content in THP-1 cells cultured with extracts of nettle fruit stalks (Urtica dioica L.). Aqueous and alcohol extracts at two concentrations were used. It has been shown that the spectrophotometric determination of protein content by the Bradford method is an effective and accurate method for determining the concentration of protein in THP-1 macrophages.

The results indicate that this method can be recommended for the determination of the protein content in other cell cultures. Key words: THP-1 cells, protein, spectrophotometer.

\section{STRESZCZENIE}

Białka są podstawowym elementem budowy tkanek, wchodzą w skład enzymów i hormonów, regulując wiele ważnych procesów życiowych. Zmiany ich stężenia kontrolują procesy metaboliczne komórki. Ilościowe oznaczanie zawartości białek podzielono na metody pośrednie (np. Kjeldahla) i bezpośrednie (biuretowa, Lowry'ego, immunoenzymatyczna, formolowa metody oparte na wbudowaniu barwników, spektrofotometrii w zakresie nadfioletu oraz oparte na zjawisku selektywnego pochłaniania promieniowania w zakresie podczerwieni). Jednym ze sposobów oznaczania zawartości białek jest metoda spektrofotometryczna opisana przez Bradford. Procedura oznaczenia stężenia protein wykorzystuje zjawisko tworzenia się kompleksu barwnik (Coomassie Brillant Blue G-250)-białko, a natężenie barwy jest proporcjonalne do zawartości białka w roztworze.

Celem pracy było sprawdzenie przydatności tej metody do oznaczania zawartości białka w komórkach THP-1 hodowanych z dodatkiem ekstraktów z owocostanów pokrzywy zwyczajnej (Urtica dioica L.). W badaniach wykorzystano wodne i alkoholowe ekstrakty w dwóch stężeniach. Wykazano, że spektrofotometryczne oznaczanie zawartości białka metodą Bradford jest skuteczną i dokładną metodą określenia stężenia protein w makrofagach THP-1.

Otrzymane wyniki wskazują, że metodę tę można polecić do oznaczania zawartości białka w innych hodowlach komórkowych. Słowa kluczowe: komórki THP-1, białko, spektrofotometr.

\section{WSTĘP}

Białka należą do podstawowych biopolimerów wchodzących w skład komórki. Są podstawowym elementem budowy tkanek, a ponadto wchodzą w skład enzymów i hormonów, regulując wiele ważnych procesów organizmu. Zmiany stężenia białek kontrolują procesy metaboliczne komórki [1]. Oznaczanie ilości białka opiera się głównie na obecności w ich strukturze atomów azotu i przeprowadza się metodami pośrednimi oraz bezpośrednimi.
Metody pośrednie (np. metoda Kjeldahla, Dumasa) polegają najczęściej na określeniu zawartości azotu i przeliczeniu go na białko, wykorzystując odpowiednie współczynniki przeliczeniowe [2].

Do najczęściej stosowanych bezpośrednich metod oznaczania zawartości białka należą: metoda biuretowa, Lowry'ego, immunoenzymatyczna, formolowa, metody oparte na wbudowaniu barwników, metody spektrofotometrii w zakresie nadfioletu oraz oparte na zjawisku selektywnego pochłaniania promieniowania w zakresie podczerwieni $[3,4,5,6]$. 
Jedną z metod oznaczania zawartości białek jest metoda opisana przez Bradford [7, 8]. Procedura oznaczenia stężenia protein wykorzystuje zjawisko tworzenia się kompleksu barwnik-białko. Wykorzystuje się zdolność wiązania barwnika Coomassie Brillant Blue G-250 (CBB-G250) z grupami aminowymi białek za pomocą wiązań jonowych i hydrofobowych. Z barwnikiem reagują głównie reszty argininy, w minimalnym stopniu reszty histydyny, lizyny, tyrozyny, tryptofanu i fenyloalaniny. Barwnik w środowisku kwaśnym ma brunatne zabarwienie, które po reakcji z białkiem zmienia się na błękitne. Wiąże się z tym zmiana maksimum absorbancji z 465 na $595 \mathrm{~nm}$. Natężenie barwy jest proporcjonalne do zawartości białka w roztworze, a wartość absorbancji jest proporcjonalna do stężenia białka. Jako wzorzec białka stosuje się albuminę bydlęcą. Liniowa zależność absorbancji od stężenia białka leży w zakresie 0,1-1,4 mg/mL.

Celem pracy była ocena przydatności spektrofotometrycznej metody oznaczania zawartości białek wg Bradford do oznaczania stężenia protein w komórkach THP-1 hodowanych z dodatkiem ekstraktów z owocostanów z pokrzywy zwyczajnej (Urtica dioica L.).

\section{METODY}

Do przygotowania ekstraktów wykorzystano owocostany pokrzywy zwyczajnej (Urtica dioica L.) zliofilizowane w aparacie Alpha 1-2 LD plus (ciśnienie 0,735 mmHg, temperatura $-20^{\circ} \mathrm{C}$ ). W celu przygotowania ekstraktu etanolowego $5 \mathrm{~g}$ suszu przeniesiono do kolby o pojemności $500 \mathrm{~mL}$ i dodano $300 \mathrm{~mL}$ $70 \%$ etanolu. Mieszaninę utrzymywano 3 godz. w łaźni wodnej $\left(80^{\circ} \mathrm{C}\right)$ pod chłodnicą zwrotną, następnie schłodzono do temperatury pokojowej i przefiltrowano. Przesącz poddano 4-krotnej ekstrakcji eterem naftowym. Alkohol odparowano na wyparce rotacyjnej pod zmniejszonym ciśnieniem. Aby przygotować ekstrakt wodny do kolby o pojemności $300 \mathrm{~mL}$, odważono $1 \mathrm{~g}$ suszu i wprowadzono $100 \mathrm{~cm}^{3}$ destylowanej wody o temp. $90^{\circ} \mathrm{C}$. Kolbę zamkniętą korkiem wytrząsano 10 min w temperaturze pokojowej, po czym przefiltrowano. W celu odparowania rozpuszczalnika przesącz poddano destylacji pod zmniejszonym ciśnieniem w wyparce rotacyjnej. Suche ekstrakty przechowywano w temp. $-20^{\circ} \mathrm{C}$.

W doświadczeniu wykorzystano komórki THP-1 (ATCC, Rockville, USA), które w ilości $3 \times 10^{6}$ posiano na 6 -dołkowych płytkach. W celu przekształcenia monocy tów w makrofagi do komórek dodawano po 100 nM PMA (phorbol 12-myristate 13-acetate) i inkubowano $24 \mathrm{~h}\left(37^{\circ} \mathrm{C}, 5 \% \mathrm{CO}_{2}\right)$. Po tym czasie komórki przemywano 3-krotnie ciepłym PBS i dodawano po $2 \mu$ g ekstraktu wodnego lub alkoholowego z owocostanów pokrzywy. Ostateczne stężenie w dołku ekstraktu wodnego wyniosło $15 \mu \mathrm{g} / \mathrm{mL}$ (PW1) i 7,5 $\mu \mathrm{g} / \mathrm{mL}$ (PW2), natomiast ekstraktu etanolowego $10 \mu \mathrm{g} / \mathrm{mL}$ (PA1) i $5 \mu \mathrm{g} / \mathrm{mL}$ (PA2). Kontrolę pozytywną (K plus) stanowiły komórki hodowane z dodatkiem $2 \mu \mathrm{L}$ DMSO (dimetylosulfotlenek), kontrolę negatywną ( $\mathrm{K}$ minus) bez dodatku tego związku. Po 48 godz. inkubacji $\left(37^{\circ} \mathrm{C}, 5 \% \mathrm{CO}_{2}\right)$ komórki zdrapywano z płytki i odwirowywano $\left(4^{\circ} \mathrm{C}, 10 \mathrm{~min}, 1800 \mathrm{obr}\right.$. $\left./ \mathrm{min}\right)$.
Supernatant odrzucano, a otrzymaną peletkę komórek zamrażano w temperaturze $-80^{\circ} \mathrm{C}$. W każdej próbce zawartość białka oznaczano w 3 powtórzeniach [7]. Oznaczenia wykonano przy użyciu spektrofotometru Agilent 8453UV.

W celu wykonania krzywej kalibracji przygotowano roztwory białka albuminy bydlęcej (bovine serum albumin - BSA) W $1 \mathrm{M} \mathrm{NaOH}$ o stężeniach: 0,05 mg/mL; 0,10 mg/mL; 0,25 mg/mL; 0,50 mg/mL i 1,00 mg/mL. Badane próbki zawierały odczynnik Bradford oraz roztwór albuminy bydlęcej zmieszany w stosunku 1:1. Ostateczne wartości stężenia wzorców BSA wynosiły: 0,025 mg/mL; 0,050 mg/mL; 0,125 mg/mL; 0,250 mg/mL; $0,500 \mathrm{mg} / \mathrm{mL}$.

Pomiary absorbancji wzorców BSA przeprowadzono przy długości fali $595 \mathrm{~nm}$. Jako próbkę referencyjną stosowano roztwór niezawierający BSA. Podczas pomiarów spektrofotometrycznych stosowano kuwety kwarcowe o drodze pomiaru wynoszącej $1 \mathrm{~cm}$. Jako próbkę referencyjną (blank) użyto mieszaninę odczynnika Bradford z 1 M roztworem $\mathrm{NaOH}$, zmieszaną w stosunku objętościowym 1:1. Próbką badaną była mieszanina odczynnika Bradford z roztworem próbki badanej w $1 \mathrm{M} \mathrm{NaOH}$, zmieszana również w stosunku objętościowym 1:1.

Z wyników otrzymanych dla poszczególnych powtórzeń obliczono średnią oraz odchylenie standardowe wykorzystując wzory:

$$
\bar{x}=\frac{\sum_{i=1}^{n} x_{i}}{n}
$$

gdzie:

$\bar{x}$ - średnia arytmetyczna

$x_{i}$ - wartość zmiennej i-tej jednostki

$n$ - liczebność obserwowanej zbiorowości

$$
S D=\sqrt{\frac{\sum_{i=1}^{n}\left(x_{i}-\bar{x}\right)^{2}}{n-1}}
$$

gdzie:

SD - odchylenie standardowe

$\bar{x}$ - średnia arytmetyczna

$x_{i}$ - wartość zmiennej i-tej jednostki (kolejna obserwacja w próbie)

n - liczebność obserwowanej zbiorowości

Krzywa kalibracji oraz jej parametry statystyczne zostały wykonane z użyciem oprogramowania UV-Visible ChemStation.

\section{WYNIKI}

Na rycinie 1 przedstawiono krzywą kalibracyjną roztworów albuminy bydlęcej.

Parametry statystyczne funkcji opisującej krzywą kalibracji roztworów BSA zestawiono w tabeli 1.

Uzyskany współczynnik korelacji kwadratowej $\left(R^{2}=0,97744\right)$ jest bliski jedności, co świadczy o bardzo dobrym dopasowaniu danych doświadczalnych do opisującej je funkcji.

Na podstawie wykonanej krzywej kalibracji oraz otrzymanego równania $\mathrm{C}=0,6789 \cdot \mathrm{A} \cdot \mathrm{R}(\mathrm{R}-$ krotność rozcieńczenia stosowana dla próbek badanych; $\mathrm{R}=44$ ) można, dokonując 


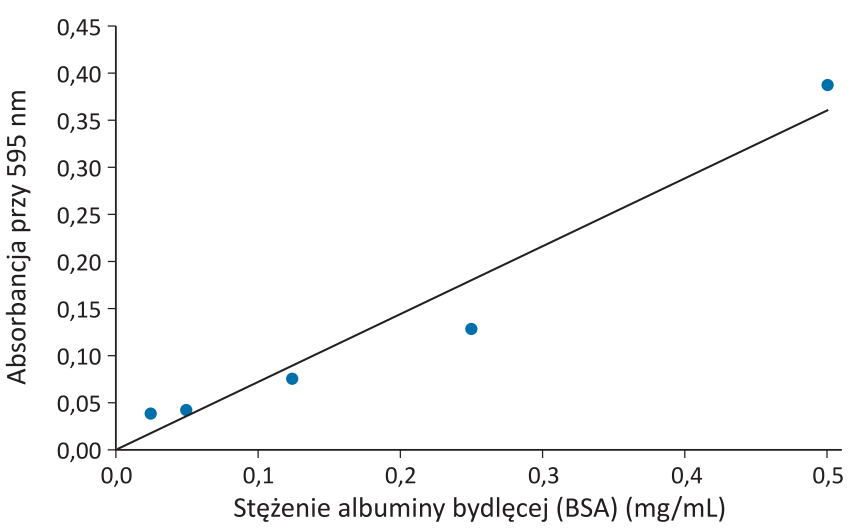

RYCINA 1. Krzywa kalibracji roztworów albuminy bydlęcej

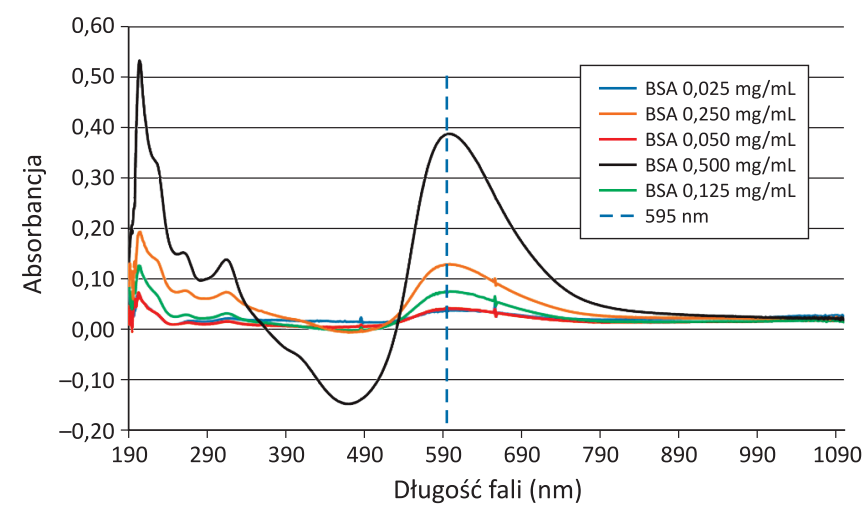

RYCINA 2. Widma Uv-Vis roztworów wzorcowych albuminy bydlęcej (BSA)

pomiarów absorbancji (A) próbek przy 595 nm, obliczyć zawartość białka w próbce wyrażoną w $\mathrm{mg} / \mathrm{mL}$.

Na rycinie 2 przedstawiono widma Uv-Vis badanych roztworów wzorcowych BSA o różnym stężeniu. Przerywaną linią zaznaczono maksima absorbcyjne przy długości fali $595 \mathrm{~nm}$, dla którego wykonywano pomiary absorbancji.

Zawartość białka znajdującego się w badanych próbkach komórek THP1 przedstawiono w tabeli 2.

Zawartość białka w komórkach THP1 była zróżnicowana w zależności od warunków hodowli. Najniższą zawartość białka $(5,58 \mathrm{mg} / \mathrm{mL})$ stwierdzono w komórkach hodowanych z dodatkiem wodnego ekstraktu z owocostanów pokrzywy o stężeniu $15 \mu \mathrm{g} / \mathrm{mL}$, natomiast najwyższą wartość $(7,70 \mathrm{mg} / \mathrm{mL})$ w kontroli pozytywnej (komórki THP-1 hodowane z dodatkiem DMSO). Niewielkie wartości odchylenia standardowego świadczą o dużej powtarzalności prowadzonych oznaczeń, wyniki są skupione blisko siebie i przede wszystkim ich rozrzut wokół wartości średniej jest niewielki.

\section{WNIOSKI}

1. Spektrofotometryczne oznaczanie zawartości białka metodą Bradford okazało się skuteczną i dokładną metodą określenia stężenia protein w makrofagach THP-1.

2. Otrzymane wyniki badań wskazują, że metodę tę można polecić do oznaczania zawartości białka w innych hodowlach komórkowych.
TABELA 1. Parametry statystyczne krzywej kalibracji roztworów albuminy bydlęcej

\begin{tabular}{lc}
\hline Nazwa wzorca & Albumina bydlęca \\
\hline Liczba wzorców & 5 \\
\hline Równanie krzywej kalibracji & $\mathrm{C}=\mathrm{k} 1^{*} \mathrm{~A}$ \\
\hline Współczynnik k1 & $0,6789 \mathrm{mg} / \mathrm{mL}$ \\
\hline Odchylenie standardowe k1 & $0,05157 \mathrm{mg} / \mathrm{mL}$ \\
\hline Odchylenie standardowe krzywej kalibracji & $0,02161 \mathrm{mg} / \mathrm{mL}$ \\
\hline Współczynnik korelacji R & 0,97744 \\
\hline
\end{tabular}

TABELA 2. Zawartość białka w komórkach THP1 hodowanych z dodatkiem ekstraktów z owocostanów pokrzywy zwyczajnej (Urtica dioica L.)

\begin{tabular}{|c|c|c|c|c|c|}
\hline \multirow{2}{*}{$\begin{array}{l}\text { Symbol } \\
\text { próbki }\end{array}$} & \multirow{2}{*}{$\begin{array}{l}\text { Powtó- } \\
\text { rzenie }\end{array}$} & \multirow{2}{*}{$\begin{array}{c}\text { Absorbancja } \\
\text { przy } \\
\lambda=595 \mathrm{~nm}\end{array}$} & \multirow{2}{*}{$\begin{array}{c}\text { Stężenie } \\
\text { białka } \\
(\mathrm{mg} / \mathrm{mL})\end{array}$} & \multicolumn{2}{|c|}{$\begin{array}{c}\text { Zawartość białka } \\
(\mathrm{mg} / \mathrm{mL})\end{array}$} \\
\hline & & & & $\begin{array}{l}\text { średnia } \\
(\bar{x})\end{array}$ & SD \\
\hline \multirow{3}{*}{$\mathrm{K}$ minus } & 1 & 0,24623 & 7,3553 & \multirow{3}{*}{7,5253} & \multirow{3}{*}{0,1910} \\
\hline & 2 & 0,25884 & 7,7320 & & \\
\hline & 3 & 0,25069 & 7,4886 & & \\
\hline \multirow{3}{*}{ K plus } & 1 & 0,25850 & 7,7218 & \multirow{3}{*}{7,7044} & \multirow{3}{*}{0,0891} \\
\hline & 2 & 0,26057 & 7,7836 & & \\
\hline & 3 & 0,25469 & 7,6079 & & \\
\hline \multirow{3}{*}{ PW1 } & 1 & 0,18097 & 5,4059 & \multirow{3}{*}{5,5880} & \multirow{3}{*}{0,2498} \\
\hline & 2 & 0,18363 & 5,4853 & & \\
\hline & 3 & 0,19660 & 5,8727 & & \\
\hline \multirow{3}{*}{ PW2 } & 1 & 0,22787 & 6,8068 & \multirow{3}{*}{6,9886} & \multirow{3}{*}{0,1661} \\
\hline & 2 & 0,23877 & 7,1324 & & \\
\hline & 3 & 0,23523 & 7,0266 & & \\
\hline \multirow{3}{*}{ PA1 } & 1 & 0,24790 & 7,4052 & \multirow{3}{*}{7,5479} & \multirow{3}{*}{0,1457} \\
\hline & 2 & 0,25249 & 7,5421 & & \\
\hline & 3 & 0,25765 & 7,6964 & & \\
\hline \multirow{3}{*}{ PA2 } & 1 & 0,20071 & 5,9955 & \multirow{3}{*}{5,9904} & \multirow{3}{*}{0,0910} \\
\hline & 2 & 0,20349 & 6,0787 & & \\
\hline & 3 & 0,19741 & 5,8970 & & \\
\hline
\end{tabular}

\section{PIŚMIENNICTWO}

1. Murray R.K., Granner D.K., Mayes P.A., Rodwell V.W.: Biochemia Harpera. Wyd. Lek. PZWL, Warszawa 2000.

2. Myszka K., Kamińska B., Fraś A., Ploch M., Boros D.: Metoda Dumasa alternatywną metodą oznaczania białka w produktach roślinnych adania porównawcze z metodą Kjeldahla. Biuletyn Instytutu Hodowli i Aklimatyzacji Roślin. 2011, 260/261, 155-161.

3. Sapan C.V., Lundblad R.L., Price N.C.: Colorimetric protein assay techniques. Biotechnol Appl Biochem. 1999, 29, 99-108.

4. Kashyap M.K., Hynd B.A., Robinson K.: A rapid and simple method for measurement of total protein in very low density lipoproteins by the Lowry assay. J Lipid Res. 1980, 2, 1, 491-495. 
5. Enechi O.C., Nwabueze C.E.: A new colorimetric method for the determination of proteins. Adv Biol Res. 2013, 7, 5, 159-162.

6. Adewale I.O., Akinseye O.R., Odutayo A.I.: Protein quantitation using dyes obtained from plant materials. Adv Biosci Biotechnol. 2012, 3, 227-230.
7. Bradford M.M.: A Rapid and sensitive method for the quantitation of microgram quantities of protein utilizing the principle of protein-dye binding. Anal Biochem. 1976, 72, 248-254.

8. Pandey N., Budhathoki U.: Protein determination through Bradford's method of Nepalese mushroom. Scientific World. 2007, 5, 5, 85-88. 